BULLETIN Bulletin hispanique

HispaniQuE Université Michel de Montaigne Bordeaux

$110-2 \mid 2008$

Varia

\title{
La construcción de la subjetividad lírica desde los itinerarios inversos de Blanco White y de Böhl de Faber
}

Luis Caparrós Esperante

\section{(2) OpenEdition \\ Journals}

Édition électronique

URL : http://journals.openedition.org/bulletinhispanique/761

DOI : 10.4000/bulletinhispanique.761

ISSN : 1775-3821

Éditeur

Presses universitaires de Bordeaux

\section{Édition imprimée}

Date de publication : 1 décembre 2008

Pagination : 487-511

ISBN : $978-2-86781-543-0$

ISSN : 0007-4640

Référence électronique

Luis Caparrós Esperante, «La construcción de la subjetividad lírica desde los itinerarios inversos de Blanco White y de Böhl de Faber», Bulletin hispanique [En ligne], 110-2 | 2008, mis en ligne le 01 décembre 2011, consulté le 19 avril 2019. URL : http://journals.openedition.org/ bulletinhispanique/761 ; DOI : 10.4000/bulletinhispanique.761 


\title{
La construcción de la subjetividad lírica desde los itinerarios inversos de Blanco White y de Böhl de Faber
}

\author{
Luis Caparrós Esperante \\ Universidade da Coruña - Espagne
}

La construction de la subjectivité et la configuration du sujet poétique sont des clefs de la poésie du XIXe siècle. Néanmoins, la poésie espagnole se heurtera à de forts obstacles religieux et politiques pour l'expression libre de la subjectivité. Dans les premières années du XIX $X^{e}$ siècle, deux auteurs, qui ne sont pas fondamentalement poètes, peuvent représenter les tendances contraires qui sopposeront pendant la période postérieure : Blanco White, exilé et hétérodoxe, et Böhl de Faber, émigré allemand et partisan des idées conservatrices.

La construcción de la subjetividad y la configuración del sujeto lírico son claves de la poesía decimonónica. La poesía española, sin embargo, tropezará con fuertes obstáculos religiosos y politicos para la libre expresión de la subjetividad. En los primeros años del siglo XIX, dos autores que no son básicamente poetas pueden representar las tendencias contrapuestas que lucharán en el periodo posterior: Blanco White, exiliado y heterodoxo, y Böhl de Faber, emigrado alemán y converso a las ideas conservadoras.

The building of subjectivity and the taking shape of the poetic persona are the keys to the nineteenth century poetry. Spanish poetry will nevertheless collide with strong religious and political obstacles in the quest for the free expression of subjectivity. In the first years of the nineteenth century, two authors who are not fundamentally poets can represent two opposing tendencies that will conflict later on: Blanco White, an exile and a heterodox, and Böhl de Faber, a German émigré - the supporter of conservative ideas.

Mots-clés : Poétiques du XIX ${ }^{\mathrm{e}}$ - Subjectivité - Lyrisme romantique.

$B H i$, Tome $110, \mathrm{n}^{\circ} 2$ - décembre 2008 - p. 487 à 511. 
$\mathrm{E}$ N CUALQUIER aproximación a las características del romanticismo español, tanta importancia tiene la exposición de sus carencias como la de sus circunstancias más visibles. Si nos ceñimos a la construcción de la subjetividad, esas carencias son más clamorosas y, precisamente, en una cuestión clave como lo es la configuración del sujeto lírico moderno. Sin duda, la búsqueda de la libre expresión de la subjetividad, lo cual implica su previa exploración, es una marca distintiva de la modernidad que adquiere matices peculiares, y más arduos, en el contexto de la lírica española del XIX. Las líneas que siguen exploran ese aspecto capital a partir de dos autores que, por parádojico que resulte, no pueden ser definidos cabalmente como poetas líricos.

Es bien conocido el interés contemporáneo por revelar una genealogía del sujeto, paralelo al proceso, tantas veces descrito, de su muerte. El paulatino descubrimiento del sujeto como instancia pragmática y discursiva aparece ya de un modo nítido en Montaigne, aunque podríamos retrotraer sus síntomas al menos hasta San Agustín, padre de la Iglesia, quien escribía: «Yo, por mi parte, Señor, trabajo duro en este campo. Y este campo soy yo mismo. He llegado a ser un problema para mí mismo, campo de dificultad y de muchos sudores" (San Agustín 1999: 259).

La cita anterior es engañosa, por razones que veremos en seguida, aunque revela bien la calidad de esa mirada hacia dentro, hacia lo que Agustín de Hipona denomina «hombre interior». En la Ilustración, sin embargo, es cuando esa conciencia adquiere su perfil actual, pues no en vano es en este momento cuando se sientan las bases de eso que llamamos modernidad. La reflexión sobre el sujeto es, en la práctica, autorreflexión, introspección. Habrá que llegar hasta Rousseau para que ese campo de trabajo adquiera toda su problematicidad y, a partir de él, excusado es decir cómo se va a convertir en el objeto favorito de la gran lírica romántica europea, quizás junto al tema del tiempo, su inevitable compañero. Pues el sujeto se hace, se transforma y se deshace en el tiempo. Ése es el terreno de la autobiografía moderna, que nace con Rousseau, y que plantea a su vez otra dualidad, la que ata vida y escritura ${ }^{1}$.

Acaso el punto central que configura el romanticismo y, desde él, la literatura posterior, sea precisamente el lugar que ocupa la conciencia del sujeto, del yo. Se trata de una conciencia conflictiva, tanto por lo que respecta al sujeto mismo y su configuración en el texto como a sus relaciones con la

1. «Parece como si hubiera sólo una experiencia del yo moderno, que señala por encima de los límites del campo de la subjetividad la del escribir(-se), que Rousseau hubiera sido el primero en realizar y que arrastra aún el discurso postmoderno de la muerte del sujeto» (Bürger 2001: 24). 
naturaleza. Uno de los postulados románticos de mayor perdurabilidad es el de la identificación absoluta entre sujeto lírico y sujeto empírico, es decir, entre quien habla en el poema y quien lo escribe. La distancia entre autor y personajes, que se acepta con naturalidad en la novela, se quiebra en cuanto el lector medio percibe un yo en el poema. Salvo en casos como el de los monólogos dramáticos, y aun aquí con matices, ese yo no es identificado como un personaje. El lector no dudará de que el sujeto de la enunciación lírica sea el propio Antonio Machado, o García Lorca, o Espronceda, o Campoamor. La principal consecuencia de esto es que la lírica sería expresión de la verdad biográfica del autor, o simplemente de la verdad, como sugiere el título que escoge Goethe para su autobiografía, Poesía y verdad. Desde entonces, la superación de esa falacia interpretativa ha sido preocupación común de teóricos de la literatura y de poetas, cada uno con sus propios recursos y tácticas discursivas.

El origen de la identificación nos remite a la relectura por August Wilhelm Schlegel, y posteriormente por Hegel, de la tripartición tradicional de los géneros de acuerdo a las tres personas gramaticales. La expresión del yo sería la propia de la lírica, la del tú del género dramático y la épica se correspondería con la tercera persona, él ${ }^{2}$. En consecuencia, se entiende que la poesía lírica es esencialmente subjetiva, la poesía dramática sería objetiva y la épica, objetivo-subjetiva. Subjetividad, como acabamos de ver, supondría que la lírica fuese un modo de enunciación alejado de los géneros ficcionales, en última instancia un género vecino de la autobiografía. Hegel enfatiza el contenido subjetivo de la poesía lírica al tratarla en su Estética:

Para ésta [la lírica frente a la épica] el contenido es lo subjetivo, el mundo interno, el ánimo que considera y siente, que en lugar de avanzar hacia las acciones se detiene más bien ante sí como interioridad y puede por tanto también tomar como única forma y meta última la autoexpresión del sujeto. Aquí no existe pues ninguna totalidad sustancial que se desarrolle como un acontecer externo; sino que la intuición singular, el sentimiento y la consideración de la subjetividad en sí replegada comunica también lo más sustancial y lo más objetivo (Sachlichste) como lo suyo, como su pasión, estado de ánimo o reflexión y como producto presente de éstos. Esta plenitud y movimiento interno no puede entonces ser una expresión mecánica en su exposición externa, como es suficiente y tiene que exigirse en el recitado épico. Al

2. Véase una detallada exposición de estas cuestiones en Dominique Combe (1999). 
contrario: el bardo debe manifestar las representaciones y consideraciones de la obra de arte lírica, como una realización subjetiva de sí mismo, como algo auténticamente sentido (Hegel 1985: VIII, 109).

La introspección, por tanto, sería una cualidad natural de la lírica que, frente a los géneros diegéticos, prefiere el discurso meditativo, donde lo exterior se funde con el estado de ánimo, o bien la expresión "como algo auténticamente sentido». La finalidad de la enunciación lírica sería lograr la empatía emocional con el lector:

Como centro y legítimo contenido de la poesía lírica se ha de colocar por supuesto el sujeto poético concreto, el poeta, sin llegar empero al hecho real y la actividad ni desarrollarse en el movimiento de conflictos dramáticos. Su única exteriorización y único acto se limita, al contrario, a que presta a lo suyo interno palabras que sea lo que fuere su objeto evidencian el sentido espiritual del sujeto que se expresa, y se esfuerzan en suscitar y mantener despiertos en el oyente igual sentido y espíritu, el mismo estado de ánimo, e idéntica tendencia a la reflexión (Hegel 1985: VIII, 207).

Esta última cita subraya igualmente, como modo esencial de la enunciación lírica, la tendencia a la reflexión, frente a la acción, ésta más propia de la épica. Lo anterior viene a significar que el movimiento o «acción» que en ella se desarrolla será de índole intelectual. La comunidad de intereses de la lírica con el discurso filosófico o científico, al margen de las obvias consideraciones estéticas, abre a su vez nuevas ramificaciones. Lo peculiar de la poesía -y no sólo de la lírica- es su modo de acceder a ese conocimiento reflexivo. Hegel le contrapone el interés de la prosa especulativa por alcanzar «el elemento ideal universal», para lo que ésta sacrifica la singularidad accidental en aras del concepto puro (Hegel 1985: VIII, 43). «Pero el pensar (Denken) tiene sólo como resultado pensamientos (Gedanken)»(Hegel 1985: VIII, 43). La poesía, por el contrario, aunque comparta fines con la filosofía, debe asentarse precisamente sobre lo singular y concreto: «El pensar es sólo una conciliación de lo verdadero y de la realidad en el pensamiento; pero la creación poética y la formación es una conciliación en la forma del fenómeno real mismo aun cuando sólo representada espiritualmente» (Hegel 1985: VIII, 43). Esto quiere decir que la poesía, asentada sobre su necesaria apariencia de espontaneidad y libertad, encuentra fundamento propio en lo particular concreto: 
La más precisa determinación que aquí se manifiesta encuentra pues su fundamento en que el arte en general gusta detenerse en lo particular. [...] Pero en la concepción y configuración poéticas cada parte, cada momento debe ser para sí interesante, para sí viviente, y la poesía se detiene por tanto con placer en lo singular, lo describe con amor y lo trata como una totalidad para sí. [...] Sobre todo debe cuidarse de pretender competir respecto de los pormenores exactos con la perfección particular de la existencia real (Hegel 1985: VIII, 48 y 49$]^{3}$.

La necesidad de concreción y la singularidad de lo accidental serían, pues, características esenciales de lo poético. Circunscrito esto a la lírica, marcada por la introspección, nos llevaría a un desarrollo mucho más libre que en los otros géneros poéticos, pero en cualquier caso dominado por su carácter subjetivizante, en el que predominan la nota sentimental enmarcada por lo singular. Las cosas, los objetos, lo particular, devienen un todo unitario con el sentimiento del sujeto de la enunciación, y lo que es más importante, dan cuerpo y forma a lo que de otro modo resultaría evanescente e inasible. Tendríamos, en última instancia, que el sujeto lírico exige la circunstanciación para hacerse creíble, y de este modo, para alcanzar con eficacia su finalidad persuasiva.

La materialización concreta de estas ideas no siempre se hizo de modo tan coherente e íntegro como podemos observarlas en Hegel. Por supuesto, ni siquiera sería necesaria una lectura directa de él, pues bastaría con esa difusión multipolar e indirecta de que habló Bloom en La ansiedad de la influencia, lo cual puede ser aun más cierto en el caso español. Lo que ocupó un primerísimo lugar en la práctica discursiva del romanticismo, entendido no como la obra de sus grandes representantes sino como cultura de época, es la identificación absoluta entre el yo elocutivo y el autor, lo que se ha denominado falacia autorial. A esto debe sumarse el papel del sentimiento, $y$ aun más, de las supuestas espontaneidad y sinceridad de su manifestación. Los distingos que hemos revisado acerca del valor de la introspección meditativa

3. También el utpictura poesis resuena en las palabras de Alberto Lista: «¿Por qué el lenguaje de la poesía procede casi siempre por cuadros e imágenes? Porque el poeta ve en su fantasía los objetos, así como el pintor. Este los traslada a un lienzo: aquel los pinta con palabras de tal manera, que el que posea el arte de la pintura, y oiga los versos, podrá pintar el mismo asunto con colores. La fantasía está más próxima a la vista y al oído que al raciocinio; como quiera que este se versa sobre ideas abstractas, desprovistas de sonido, de movimiento, de color» (Lista 1844: 23). 
o de la necesidad de concreción ocupan un segundo plano, aunque -ahora debe decirse- no sea éste el caso de los grandes románticos.

La delimitación del sujeto lírico, el descubrimiento de sus perfiles puramente literarios, no resulta fácil para los líricos españoles del romanticismo. Los poetas ilustrados podían campear con más seguridad en esos terrenos porque se sentían amparados por unos moldes expresivos dados, codificados, desde los que se podía tentar con menos riesgos la expresión de lo personal. La situación del romántico es más delicada, habida cuenta de su ruptura con el utópico mundo pastoril o con las convenciones genéricas. $\mathrm{El}$ imperativo de verdad -más que de verosimilitud- exige, como escribía Hegel, una circunstanciación que se vuelve arriesgada cuando el objeto es uno mismo. Anotemos al vuelo la importancia paralela que esto tendrá para el paisajismo, otro aspecto esencial del romanticismo. ¿Dónde se ancla la expresión de algo tan evanescente como es la propia subjetividad? ¿Dónde se cifra lo particular hegeliano? ¿Quién habla en el poema? ¿Si ya no está a la sombra de la encina virgiliana, dónde habla el sujeto, o al menos, dónde vive? ¿A quién se dirige? La falta de estas concreciones en la nueva poesía producen en la mayoría de los casos esa sensación de palabrería, de frases hechas, de tópicos resobados que nos invaden al leer los poemas españoles de la época. Porque no es sólo la concreción material, el escenario físico, sino que la poesía subjetiva exige al menos una circunstanciación emocional que supere el marco tópico del "corazón desgarrado» o el llorar «sólo por haber nacido». También aquí hay que llorar por algo concreto, aunque ese algo concreto sea el deseo infinito que, no se olvide, rompe contra los sucesos de la vida cotidiana.

Desde luego, sería una explicación simplista achacar esto a carencias expresivas o, lisa y llanamente, a falta de altura poética. Bastaría confrontar estos modos de la llamada poesía subjetiva, necesariamente volcada en el presente, con los que se dan en el terreno de la poesía histórica o legendaria, con su minuciosa construcción de las circunstancias, incluso vestimentarias, de sus héroes. Precisamente, aquello que echamos en falta cuando del propio yo y del ahora se trata. Aunque no se puede olvidar que el abandono de la narratividad es una de las condiciones, que no limitaciones, de la poesía subjetiva.

De este modo, la debilidad de los poemas puede explicarse casi siempre por la desaparición de la circunstanciación y por la facilidad con que la voz quejumbrosa del yo se hunde en abstracciones morales y seudofilosóficas. La consecuencia, extensible a la mayor parte de los poetas del momento, es que lo que debiera ser una meditación creíble, con sabor a cosa vivida, esto es, la expresión de un sujeto singularizado ante problemas también singularizados, se difumina entre lugares comunes y retórica desgastada. 
Quizás lo más grave sea que los poetas no parecen ser conscientes de estas limitaciones. Confesionalismo lo hay, pero confesiones pocas. Lenguaje de la intimidad, también, pero apenas reflexión introspectiva. Ideas originales, escasísimas. El drama de Gil y Carrasco, de Nicomedes-Pastor Díaz, como el de tantos otros poetas del momento, está en la imposibilidad de trascender este estado inmaduro, aunque potencialmente fecundo, de su musa. Parece como si el diseño confesional de los poemas tropezase con el muro inexpugnable del pudor. ¿Cómo iba a desnudar su intimidad el periodista conocido, el funcionario público, el jefe político, el parlamentario? ¿Y cómo hacerla además creíble, precisa, concreta? El ensimismamiento es siempre peligroso, y aunque parezca paradójico, exigiría del poeta consciente un enriquecimiento de los datos sensibles y de lo que podríamos llamar la psicología de las emociones, de la materia concreta sobre la que se alza la meditación. Ejemplos no les faltaban entre los poetas más admirados en ese momento, fuesen Hugo o Lamartine o Byron. Aquí, sin embargo, solamente cabe lo que pudiéramos llamar la exterioridad del sentimiento:

Un mezquino mortal que sufre y llora

Luchando con el mundo en que nació;

Un mortal que a los ángeles adora

Porque en el mundo qué adorar no halló (Díaz 2006: 174).

Don Juan Valera, tan reacio a las romantiquerías, apuntaba directamente estas carencias cuando recordaba con humor el fervor poético que sacudía los salones madrileños de aquellos años:

Y a la verdad, no sólo en el Ateneo y en el Liceo, sino en tertulias literarias a nativitate, o que se convertían en literarias, se recitaban versos que se escuchaban con admiración y eran muy celebrados. Lo nebuloso e indistinto de las ideas y la incoercible vaguedad de los conceptos solían prestar a estos versos su mayor hechizo. Cada cual, y sobre todo las mujeres, se los explicaban como les daba la gana; arrullado el oyente por el sonsonete o la melopeya, imaginaba lo que era más de su agrado y se deleitaba, gozando de ello, en éxtasis o en arrobo. Tales coplas sugestionantes y llenas de misterios llegaron al colmo de su perfección cuando se escribían para que se recitasen, y luego se recitaban al compás de un vals, de una polca o de otra sonata por el estilo (Valera 1942: II, 1203). 
En estas circunstancias, las posibilidades de adaptación de la lírica española a los nuevos retos que presentaba la modernidad literaria van a ser escasas. Las respuestas de la lírica europea cuando se alcanza la segunda mitad del XIX plantean un segundo grado en esa relación conflictiva, incluso angustiosa, entre la instancia vital y la elocutiva, del mismo modo que se plantea una relación de nuevo conflictiva entre el lenguaje coloquial y el lenguaje puramente literario. Entonces surge esa idea, con ecos nietzscheanos, de la muerte del sujeto.

La causa está en el agotamiento del romanticismo, especialmente en sus aspectos más hipercaracterizadores, lo cual produjo, como rasgo más visible, la reacción contra los excesos sentimentales y su exhibicionismo. La concepción anterior, lógicamente, era uno de sus soportes básicos. Entraría entonces en crisis la concepción del sujeto lírico como proyección fiel del autor y del poema como «algo auténticamente sentido». No obstante, y esto conviene subrayarlo, persistiría como un factor inexcusable de la modernidad el interés por la circunstanciación, el apego a las cosas concretas, al objeto. Dicho de otro modo, y esto es indicativo del cambio de perspectiva, lo que antes era un mecanismo de autentificación del sujeto pasaba a serlo de autentificación del propio poema.

La modernidad literaria, tal como la define en teoría y práctica Baudelaire, comenzaría entonces por rebajar la inmediatez del sujeto lírico en busca de una creciente impersonalidad, que alcanza sus extremos en Rimbaud y Mallarmé. Desde entonces, el «je est un autre» de Rimbaud se convierte en referencia inevitable para buena parte de los poetas contemporáneos. $\mathrm{O}$, simplemente, la multiplicidad de yoes posibles acaba por situar en un plano de incertidumbre la anterior solidez del sujeto lírico ${ }^{4}$.

De nuevo, en el caso español ese debate se elude, en buena medida como consecuencia de la falta de madurez de las propuestas anteriores. La profunda desconfianza ante el subjetivismo era ante todo ideológica e ideológicas van a ser, en su sentido más inmediato, las respuestas.

Los itinerarios vitales contrapuestos de Blanco White y de Böhl de Faber, aunque sólo el primero ejerza de lírico en español, y eso dentro de cánones ilustrados, permiten un acercamiento fructífero a las bases ideológicas de un debate que marcará el curso de la poesía a lo largo del XIX.

4. «La modernidad, a mi juicio, se estatuye y es definible en tanto que proceso revolucionario de subjetivización del arte y del pensamiento, y en su final, en su desarrollo último perteneciente a los neopositivismos y a la Vanguardia histórica, describe una reinversión en su centro, en el Sujeto; es decir, una disolución del mismo o, dicho de otra manera, una desubjetivización objetualizadora, epistemológica al igual que artística» (Aullón 2000: 23). 


\section{Sujeto y poder: el diagnóstico temprano de Blanco White}

Hablamos de literatura, pero no podemos olvidar que en la época contemporánea la autorreflexividad es tanto un problema de discurso como una cuestión de poder, aspecto sobre el que ha insistido Foucault (2001). Blanco White es la expresión más evidente de esa faceta. Él es la figura española moderna que antes y de modo más complejo ejemplifica el proceso de construcción autorreflexiva, la de un alma puesta al desnudo, algo insólito en el panorama literario español hasta bien entrado el siglo XX. Más allá del largo ninguneo que sufriría hasta nuestra época y más allá de la paralela fascinación que podemos experimentar hoy ante su itinerario vital e intelectual, lo cierto es que Blanco resulta inexcusable para quien quiera enmarcar los cambios de mentalidad que se dan en el tránsito del siglo XVIII al XIX españoles. ¿Cómo no reconocer a un contemporáneo nuestro en el retrato pretendidamente destructor que le dedicó Menéndez Pelayo?:

No nos indignemos con Blanco: basta compadecerle. Era el renegado de todas las sectas, el leproso de todos los partidos, y caminaba al sepulcro sin fe en su misma duda, temeroso de lo mismo que negaba, aborrecido de muerte en España, despreciado en Inglaterra (Menéndez Pelayo 1998: 817).

Blanco no está exiliado del sistema literario español, aunque el grueso de su obra apareciese en inglés. No sólo eso. Su mirada adquiere para nosotros un valor especial, dada su estrecha relación tanto con la iglesia católica espańola, en la que se forma y en la que llega a ser sacerdote, como con el entorno cultural que representa ejemplarmente su influyente amigo Alberto Lista. Por otro lado, su doble huida de Espańa, tanto en el terreno físico como en el espiritual, y su tardía reeducación en el ambiente cultural y religioso británico le dan una perspectiva que, para ser justos, viene a ser al menos el reflejo invertido de la de Böhl de Faber.

La heterodoxia de Blanco White abarca lo político y lo nacional, pero donde se reveló realmente insoportable para el pensamiento oficial fue en el terreno religioso, pues la religión era y había sido el cemento de la vida española, fuese desde el confesonario rural o desde los palacios de la Inquisición. Más concretamente, lo que Blanco White definió como «sistema nacional de religión» (1982: 137) chocaba frontalmente con el espíritu liberal, en el que debemos enmarcar necesariamente los elementos más innovadores en el terreno literario. Y subrayo esa palabra, para oponerlo al romanticismo reaccionario que propugnaba por esos años Böhl de Faber. 
Por lo mismo, la desconfianza de Blanco hacia los liberales españoles nace de la progresiva aceptación de ese sistema de poder religioso por parte de ellos. Los cambios políticos que exigía la sociedad española no eran posibles, en su opinión, sin la ruptura con el control ideológico que mantenía la Iglesia. O dicho de otro modo, la liberación política solamente sería posible tras una liberación cultural.

Hablamos de construcción de una subjetividad moderna. La Iglesia española no era sólo hostil al liberalismo. Era, desde luego, enemiga acérrima del libre pensamiento, como lo era en realidad de todos los síntomas de modernidad que habían aportado los llamados filósofos. Desnudarse moralmente -sin trascendencia docente o religiosa- equivalía para ella al desnudo físico. Frente a la irrupción de esas corrientes cada vez más pujantes, en cuanto expresión del auge de la mentalidad burguesa, la Iglesia opondrá el confesonario como su arma más eficaz. Eficaz, sobre todo, para el control de la subjetividad. No extrańa, por tanto, que para Blanco el factor más negativo que destaca una y otra vez sea el sacramento de la confesión:

Ahora bien, en un país donde la conciencia de los individuos está sometida al control de otra persona y así sucesivamente en una interminable cadena de rendiciones morales, no es la inmutable disciplina de la decisión personal la que decide el deber, sino que todo se hace por obediencia a opiniones ajenas, y aún esa misma obediencia está sometida a un supremo poder dispensador. Por tanto, si una persona puede obtener una opinión favorable a sus propios deseos, la responsabilidad moral de la acción recae entonces en el consejero y el interesado tiene plena libertad de hacer su voluntad. Por su parte, el consejero al no tener conciencia de la acción, tampoco puede sentir remordimientos y así, como consecuencia lógica del sistema, a la moralidad del país, salvo en el caso de personas excepcionales, le falta el firme fundamento de la responsabilidad personal (Blanco White 1988: 64).

Por supuesto, el fondo de esta opinión descansa en su asunción del protestantismo como ética de la «responsabilidad personal», lo cual, como no hará falta decir, en nada disminuye el valor de su diagnóstico 5 . En otro lugar

5. «A pesar de que bajo la denominación de Protestantismo se agrupa un conjunto de tendencias y grupos religiosos muy diferentes, todos tienen en común su impacto en las formas culturales mediante un énfasis en la validez de la conciencia individual, el juicio personal y la respuesta íntima para las cuestiones morales y religiosas. Esta atención a lo individual 
de su Autobiografía precisa aun más, y de modo más ajustado al propósito de este trabajo:

No voy a insistir en las razones de mi convencimiento de que la confesión auricular es una de las prácticas más malignas de la Iglesia de Roma, porque ya lo he tratado detenidamente en otro lugar. Los que conocen algo de filosofía moral saben muy bien que esta minuciosa atención a las faltas personales, no para conocer su causa profunda en el corazón sino para discernir si son pecados veniales o mortales según criterios ajenos, esta minuciosa atención, digo, tiene que impedir en la mayor parte de los casos el desarrollo normal de la conciencia personal e incluso puede llegar a destrozarla en muchos casos (Blanco White 1988: 76).

También sería apropiado recoger sus precisiones, en el mismo sentido, acerca de las diferencias entre la oración mental y la meditación católicas, dirigidas desde fuera por un director espiritual o mediante un protocolo rígido, con la libre introspección individual. Susan Kirkpatrick, apoyándose en Foucault, recuerda no obstante cómo la práctica de la confesión, en su desarrollo setecentista, tuvo como parádojico resultado el afianzamiento de una conciencia individual y moderna:

En tanto que este minucioso examen convertía la experiencia interior en lenguaje y promocionaba la autorreflexión, la confesión, tal y como se practicaba en el siglo XVIII, tenía el potencial de incubar en forma embrionaria ese yo individualizado que corresponde a la sociedad liberal, burguesa y capitalista que denominamos modernidad (2001: $30)$.

Kirkpatrick aplica esta idea a la formación de la conciencia crítica del propio Blanco, tal como lo reflejan sus memorias, en donde la angustia que precede a la confesión auricular es precisamente la que desata el proceso de cuestionamiento introspectivo. La idea revela lo contradictorio de este proceso de autorreflexión, del que no resulta aventurado decir que nace en el seno de la Iglesia pero del que, llegado a cierto punto, la misma Iglesia

condujo por una parte a la insistencia en la independencia del yo íntimo expresada en forma de exigencia de «libertad de conciencia» y por otra parte al cultivo de la introspección como medio de afirmación de los verdaderos impulsos del alma» (Kirkpatrick 1991: 15). 
se desmarca ${ }^{6}$. Como es habitual en todo lo referente al desarrollo de la Ilustración, la puesta en marcha de propuestas innovadoras produce resultados contradictorios, incluso paradójicos. La introspección que propicia la Iglesia no está muy alejada de lo que muestran las Confesiones de San Agustín, en quien la subjetividad se muestra como alteridad, es decir, en donde el yo es descrito y analizado desde la perspectiva de Dios:

Los libros prestados me enseñaron a volver a mí mismo. Guiado por ti entré en el interior de mi alma y esto fue posible porque te hiciste mi ayuda. Entré y con el ojo, sea cual fuere, de mi alma vi la luz inmutable que proyectaba sus rayos sobre el ojo mismo de mi alma y sobre mi mente. No era la luz ordinaria del día que puede captar el ojo de cualquier ser vivo de carne y sangre, ni otra luz de su misma especie, aunque mayor. Era como si la luz del día brillara mucho más intensamente y llenase todo el espacio de un inmenso resplandor. Lo que yo veía era algo completamente diferente de cualquier luz. No brillaba sobre mi mente, a la manera que el aceite flota sobre el agua o el cielo cuelga sobre la tierra. Estaba sobre mí porque era la misma Luz que me hizo, y yo estaba debajo porque fui hecho por ella. Todo el que conoce la verdad conoce esta luz, y quien conoce esta luz conoce la eternidad. El amor es quien conoce esta luz (San Agustín 1999: 170-171).

De este modo, la experiencia de la interioridad remite automáticamente a algo externo y superior al mismo sujeto. Es una forma de alienación. En ese sentido hay que entender su afirmación en De vera religione: "Noli foras ire, in te ipsum redi; in interiore homine habitat veritas» ${ }^{7}$. Las reticencias de Voltaire, el adversario de Rousseau, ante la introspección se explican precisamente por ese trasfondo religioso, todo lo cual chocaba con su búsqueda de una razón iluminadora y activa ${ }^{8}$. Fuese como fuese, el

6. Alain Corbin analiza en el caso francés, hasta mediado el siglo XIX, ese doble papel de la confesión que, por una parte, banaliza la introspección y, por otro, inclina irremediablemente a una laicización de su ejercicio, mas siempre en el marco de una religión que exige sumisión y culpabilización mediante la penitencia (Corbin y Perrot 1989).

7. «No salgas fuera, retorna a ti mismo! En el hombre interior habita la verdad.» Tomo la cita de Bürger (2001: 30), quien la comenta en el sentido que aquí se propone.

8. «Si en Voltaire el sujeto de la Ilustración se escapa a nuestra mirada, ello es porque no se quiere ver a sí mismo. El hallazgo se puede interpretar de modo diverso: como acto de liberación que le quita al hombre la sensación de culpa y le capacita con ello ante todo para convertir la propia felicidad y la de sus congéneres en meta de su acción; pero también como 
camino estaba abierto y el libre desarrollo de la subjetividad en el mundo contemporáneo no admitiría mediadores.

Volvamos a Blanco. En uno de los pasajes de Cartas de España ejemplifica en su propia madre la tensión angustiosa que provoca el asomarse sin asideros a ese pozo misterioso y negro de la subjetividad:

Si mi madre hubiera llegado a ser una visionaria, hubiera dejado de sufrir, pero poseyó hasta el fin de su vida una fuerza intelectual capaz de todo menos de algo que era totalmente incompatible con la religión de su patria: escudrińar sin miedo en el oscuro rincón en que se ocultaban los fantasmas que la atormentaban (1977: 83).

El catolicismo controla con mano firme ese acceso. Lo hace, como repite Blanco, mediante el poder físico y mental del confesonario. Pero este instrumento, para quien como Blanco lo cuestiona todo, es un instrumento de tortura. Él mismo, sacerdote católico, ha sufrido ese tormento interior, mezclado inevitablemente con fuertes dosis de vergüenza, humillación y remordimientos, y lo ha hecho tanto desde la perspectiva del sujeto como del objeto de la alienación. Estos sentimientos forman parte, como reitera, de la educación sentimental de tantos y tantos católicos. Llega así a definirse "como uno a quien la providencia ha encargado una misión especial, la de dar testimonio de ciertas experiencias espirituales ante aquéllos que puedan leer mis escritos» (Blanco White 1988: 262).

Incluso así, su enfrentamiento con el catolicismo dominante aparece matizado por una conciencia histórica que le permite distinguir entre ese «sistema nacional de religión» y la conciencia concreta e individual de los católicos, de la que su propia experiencia es muestra ${ }^{9}$. No en vano señalará

renuncia al conocimiento mediante el que el sujeto ilustrado se apantalla contra su propio yo y sus impulsos impredecibles. Si se intenta pensar a la vez ambas interpretaciones, resulta entonces una imagen profundamente contradictoria de la Ilustración» (Bürger 2001: 90).

9. Blanco White precisa con generosidad, y en más de una ocasión, que, aunque este catolicismo nacional sea un obstáculo para las libertades, eso no significa que lo sean los propios católicos. En nota a la primera edición de sus Cartas de España, escribe: «No puedo decir, sin embargo, que no crea firmemente en esta tendencia general que he atribuido al catolicismo. Pero hay que distinguir entre un catolicismo en pleno y libre crecimiento y la misma planta dañina castigada y suavizada por la sombra del protestantismo. De esta manera, mientras que estoy persuadido de que la religión de España, Portugal y Nápoles es el principal obstáculo para el establecimiento de la libertad en estos países, niego enfáticamente la conclusión de que los católicos harán necesariamente y en cualquier circunstancia mal uso del poder político" (1977: 87-88 n.). 
la lectura del padre Feijoo como un hito decisivo en su propia liberación (1977: 99) ${ }^{10}$. Veremos después cómo a lo largo del XIX se reivindicará desde el liberalismo, incluso desde el anticlericalismo, la literatura espiritual del XVI, algo paradójico sólo en apariencia, pues en autores como Teresa de Jesús, después integrados por la Iglesia oficial, se encuentra esa misma actitud valiente y crítica, pero ante todo, libre de conciencia.

Pero más grave que la imposibilidad de manifestar libremente el pensamiento -digamos, hacia fuera- es la imposición de un molde mental desde la infancia que actúa como cancerbero del desarrollo de la propia personalidad. Blanco White, como Quintana, le da a este conflicto moral una dimensión que abarca también el campo de la literatura. Achaca el retraso de las letras españolas en relación a las europeas de su tiempo a la presión y opresión políticas y religiosas. El intelectual español, incluso el más librepensador, lleva dentro el virus de su propio enemigo, de tal modo que ya no es que hablar libremente en España sea imposible, sino que pensar en libertad constituye en sí una lucha agónica:

Si yo pudiera dibujar con acierto el cuadro de un espíritu juvenil y sincero en lucha con los obstáculos que la educación española pone a sus progresos, su alarma ante la continua sospecha de ir caminando voluntariamente hacia el error, el miedo supersticioso que estorba sus primeros anhelos de libertad, la honesta e ingeniosa casuística con que se persuade a abandonar el sendero prescrito, la alegría y el miedo virginal del primer pecado, el amor creciente a la verdad recién descubierta y el consiguiente odio a sus tiranos, la desesperación final y el fiero paroxismo que lo dominan al saber su perdición inevitable, al ver con evidencia espantosa que sus mejores esfuerzos se han perdido y que la ignorancia, el fanatismo y la superstición exigen, y pueden conseguir, que se les rinda homenaje; si yo fuera capaz de pintar todo esto, no creo que ningún argumento de novela sería capaz de suscitar mayor interés en los que no son indiferentes a las más nobles preocupaciones de la humanidad (1977: 108-109).

Blanco White, sin embargo, mantiene un fuerte recelo hacia el exhibicionismo de esa subjetividad crítica, al menos en un plano teórico, y manifiesta

10. Por lo mismo, Chateaubriand, «al comprometer los sentimientos y la fantasía en defensa de su fe» frente a «la seca y sosa filosofía de sus compatriotas», apuntalaría las creencias de White durante algún tiempo (1977: 120). No es casual que el catolicismo amable y estético de Chateaubriand fuese censurado por los eclesiásticos españoles de entonces. 
distancias ante quien es de hecho uno de sus fundadores en la literatura moderna, Rousseau:

No poseo el cinismo intelectual que me permitiría, como a Rousseau, exponer mi corazón desnudo ante la mirada del mundo. Tampoco tengo su desafortunada y odiosa propensión a expresarse con afectada franqueza, ni su cautivadora elocuencia para pregonar las buenas cualidades que pudiera poseer, y como para comenzar la tarea de describir los sufrimientos de mi corazón y mi alma he de vencer no pequeña resistencia y el sentimiento del decoro, tengo algún motivo para creer que lo que me lleva a hacerlo es el sincero deseo de ser útil a los demás (1977: 79-80).

De este modo, Blanco interioriza una de las contradicciones esenciales del movimiento ilustrado hacia el romanticismo, que en el fondo comparte con Rousseau: la tensión entre su conciencia de singularidad, que se expresa inevitablemente mediante la narración de experiencias concretas, y el imperativo ilustrado de universalidad y ejemplaridad. Esa conciencia de excepcionalidad es desde luego determinante en Rousseau, y bastaría con citar el primer párrafo de sus Confesiones, pero esto contrasta al mismo tiempo con la primacía de lo universal en el pensamiento oficial de la Ilustración. También Rousseau deberá justificarse ante las críticas de quienes, como Voltaire, ven una renuncia política en su alejamiento de la sociedad. El conflicto es también uno de los ejes de las Cartas marruecas de Cadalso, cuyo Nuño Núñez se confiesa misántropo mientras critica a la vez a quienes, como el hidalgo de la carta LXX, se recluyen en la naturaleza y dejan de ser útiles socialmente ${ }^{11}$.

No solamente es eso. No es solamente la capacidad del poder, de cualquier poder, para modelar las formas correctas de subjetividad. El retrato de uno mismo que abordan Blanco o Rousseau es también el de una figura en movimiento. El itinerario vital de Blanco es bien expresivo de esa cadena

11. «Pero, Gazel, volviendo a tu huésped y otros de su carácter, que no faltan en las provincias y de los cuales conozco no pequeño número, ¿̨no te parece lastimosa para el estado la pérdida de unos hombres de talento y mérito que se apartan de las carreras útiles de la república? ¿No crees que todo individuo está obligado a contribuir al bien de su patria con todo esmero? Apártense del bullicio los inútiles y decrépitos: son de más estorbo que servicio; pero tu huésped y sus semejantes están en la edad de servirla y deben buscar las ocasiones de ello aun a costa de toda especie de disgustos. No basta ser bueno para sí y para otros pocos; es preciso serlo o procurar serlo para el total de la nación» (Cadalso 2000: 174-175). Es el mismo Nuño que envidia en la carta XXI el retiro del sabio Ben-Beley. 
de imágenes sucesivas y contradictorias, de luchas y fracasos, de triunfos siempre postergados que el escritor intenta resolver mediante la escritura autobiográfica. En definitiva, el yo moderno es esencialmente un yo fluido, inasible, que se vive como contradictorio e insatisfactorio: «El yo moderno se encontraría inmediatamente como un yo que se sabe diferente de todos los demás» (Bürger 2001: 149)... e incluso de sí mismo (Bürger 2001: 149). Ese filón será trabajado a fondo por la modernidad literaria, desde la dolorosa fragmentación del yo romántico hasta su reconsideración en el poema por el simbolismo. Mientras tanto, el renegado Blanco, el leproso Blanco, y aquí podríamos citar de nuevo a Menéndez Pelayo, "caminaba al sepulcro sin fe en su misma duda» (1998: 817).

\section{Poder o sujeto: las insuficiencias de Böhl de Faber y de Durán}

¿Y al margen del self-banished Blanco, cómo se reflejan estas tensiones sobre el suelo español? Al principio hablaba de carencias. Que hubiese carencias a la hora de expresarlas no supone, sin embargo, que no existiesen las tensiones. Precisamente, la conciencia de ello, por vaga y peligrosa que se les apareciese, es manifiesta. Los síntomas son variados, sea el placer exhibicionista con que Espronceda se desnuda ante los lectores, o la conciencia de culpabilidad de Pastor Díaz, o la búsqueda de la disolución del yo conflictivo en la naturaleza rosaliana. En todos los casos, la recepción de estas ideas en la España romántica es desigual y deslavazada, posiblemente más por vía del ejemplo ofrecido por las lecturas de los grandes autores del momento que por reflexión teórica.

Fuese como fuese, la irrupción del romanticismo, aquí como en todas partes, hace bandera de esta nueva concepción del poema, circunstanciado, ligado a la persona del poeta, expresión de una experiencia sentimental y verdadera. No obstante, también aquí como en todas partes, la centralidad de la poesía lírica -esencialmente, poesía subjetiva-compite con la presencia muchas veces dominante de subgéneros prestigiados en la tradición del romanticismo conservador, como pueden ser la poesía legendaria o la histórica, que anulan o rebajan la pertinencia del sujeto ${ }^{12}$. Estas modalidades,

12. Aunque eso no los excluye del campo de la lírica, como matiza el propio Hegel: «Así como en el epos encontramos muchas clases que tendían hacia el tono lírico de la expresión, también la lírica puede adoptar como su objeto y su forma un acontecimiento que es épico según el contenido y la apariencia externa y en consecuencia es capaz de aproximarse a lo épico. A este tipo pertenecen, por ejemplo, las canciones heroicas, los romances, las baladas. [...] Lo que en verdad intenta producir el poeta en el oyente es la misma disposición anímica 
que en el contexto de este trabajo interesan mucho menos, son centrales en el romanticismo español y el hecho es ya en sí revelador, pues desdibujan el sujeto lírico y se alejan así de la modernidad ${ }^{13}$.

Habría que añadir que la subjetividad romántica se asocia frecuentemente al modelo germánico, siguiendo en esto de nuevo a August Schlegel. En el arquetipo construido por este autor, la nostalgia, la melancolía, el sentimentalismo vago y sin objeto definido, corresponderían al carácter propio de los pueblos del Norte:

La nature sévère du Nord force l'homme à rentrer en lui-même; mais ce qu'il perd du côté des développements brillants d'une imagination sensuelle, tourne au profit des dispositions plus nobles et plus sérieuses de son âme. C'est ce que prouve la franchise avec laquelle les anciens peuples germains embrassèrent le christianisme (Schlegel 1971: 44).

Los «desarrollos brillantes de una imaginación sensual», propios del carácter mediterráneo, no faltarán desde luego en el romanticismo español, como prueba Zorrilla. Más dudoso es el predominio de la introspección, según Schlegel condicionada por la severidad de la naturaleza norteña, salvo en casos puntuales. Esto es un buen índice de la levedad con que el modelo es recibido. Lo que realmente cuenta en la apropiación que se hará en España de estas ideas no es ni puede ser la introspección, siempre bajo sospecha, sino la ligazón entre literatura y cristianismo, sin mayores matices.

En la temprana defensa del romanticismo schlegeliano que emprende Juan Nicolás Böhl de Faber encontramos la antítesis de cuanto vimos en Blanco White. Adelantemos sin embargo que Juan Nicolás Böhl de Faber es una excepción en el panorama generalizado de ignorancia de lo alemán que se da en España, y no sólo por el hecho obvio de serlo él. Estamos ante un hombre indudablemente culto, cosmopolita, educado en las mismas ideas ilustradas que combate, buen lector del primer romanticismo inglés y alemán, y que arrastra a pesar de ello el fervor del converso en sus ideas políticas y religiosas. Induce al máximo respeto el hecho de que, en 1819 y en Cádiz, Böhl le escriba a un corresponsal que Wordsworth es «el poeta que

que provoca en él el acontecimiento narrado y que ha transferido pues íntegramente a la representación. [...] Así el contenido es por supuesto épico, pero el tratamiento es lírico» (Hegel 1985: VIII, 193).

13. Algo paralelo ocurre en el caso de la pintura, con la competencia entre las modalidades paisajísticas, muy pobres entre los españoles, y las modalidades de pintura histórica, que son las más prestigiadas a lo largo del XIX. 
más me ha impresionado y que, junto con Goethe, más me ha iluminado» (Carnero 1978: 214).

A grandes líneas, ese romanticismo puramente teórico que se define a partir de él durante el período que va hasta 1833 ó 1834 se enmarca inevitablemente en terreno ideológico o francamente político, más que literario. Dígase lo que se diga, la reivindicación de Calderón y del llamado teatro áureo no acaba de situar la polémica en el terreno de los textos y mucho menos en el de la creación. Se trata ante todo de una defensa cerrada de esa misma España que a Blanco le resultaba asfixiante, donde cualquier tufillo de librepensamiento o de duda convertía al discrepante en reo del aparato represor ${ }^{14}$. Incluso Böhl, en muchos aspectos, elabora una curiosa e interesada mezcolanza entre el sistema literario que propugna Schlegel y las ideas políticamente exaltadas de Antonio Campmany en su Centinela contra franceses, de 1808. ¿Podemos aun así hablar de romanticismo? Schlegel, que no era precisamente un revolucionario, llegó a romper discretamente su relación epistolar con sus exaltados intermediarios, Böhl y su mujer. Admitamos, aun así, que ahí estaba germinando la vía española dominante al romanticismo, al menos en la medida en que desvió la atención hacia la recuperación de modelos literarios autóctonos y, por añadidura, aunque esa recuperación tenga que tardar todavía bastantes años para hacerse efectiva.

Desde luego, en la concepción que maneja Böhl de la literatura está desterrado el sentido moderno de subjetividad. Pisamos un terreno político abonado de minas ideológicas. Al margen de su gusto particular o de sus buenas lecturas, o bien al contrario, precisamente por su experiencia de ellas, entiende la literatura como un debe ser, como un medio docente al servicio de la difusión de ideas políticas antiliberales. En este sentido, y sólo en éste, habría que dar la razón a Flitter cuando sienta en él y en su ideario las bases de lo que va a ser el romanticismo dominante en España ${ }^{15}$. Böhl da por

14. Javier Herrero (1971: 222) ilustra bien el ambiente ideológico posterior a la asunción del trono por Fernando VII: «El sentimiento de horror hacia Francia se exaltará y elevará a un tono de frenesí, identificando «francés» con «ateo» y «sacrílego» y uniendo la defensa de la patria española con la de la religión católica. Fe católica y espańolismo se identifican; la guerra contra los franceses se convierte en una cruzada religiosa, y la cultura ilustrada se define no ya como una traición a la patria, sino como blasfemia destructora del mundo católico y español. Contra enemigo tan perverso toda insolencia es poca. Espańa se divide en dos bandos irreconciliables: los santos católicos, españoles castizos, monárquicos netos y absolutos, y los impíos liberales, agentes de Napoleón, traidores a la patria y miembros de una conspiración internacional para destruir la sociedad, la Iglesia y las instituciones tradicionales. Todo compromiso es impiedad, pacto con el demonio; no hay más solución que el exterminio.»

15. La conocida tesis de Derek Flitter (1995: 4), que parte de estas teorizaciones y margina 
sentado que la poesía moderna «se funda sobre los sentimientos religiosos, sobre el heroísmo, el honor, y sobre el amor», todo lo cual explicaría que «en España precisamente había de adquirir su más alta perfección» (apud Carnero 1978: 167). La hostilidad del autor hacia el espíritu ilustrado, aquel que alimenta a Blanco en su crítica de la situación española, le lleva a afirmar que

Tal es la filosofía moderna. Los espańoles parecen haberse libertado con sólo unas viruelas volantes o locas, mientras que las señales de una irrupción maligna desfigura las fisonomías de las demás naciones. En su existencia peninsular han pasado en modorra el siglo XVIII; y en efecto, ¿qué mejor podían haber hecho? (Carnero 1978: 167) ${ }^{16}$.

Estamos ante una idea que, entre otros, ha sido utilizada por Octavio Paz para explicar la pobreza de la modernidad literaria hispánica: la debilidad de nuestra Ilustración, que es su base natural y, pese a Böhl, también la base natural desde la que se desarrollan las innovaciones románticas. Claro que para él la negación de la modernidad pasa a ser virtud, como vemos. A su lado, el contrincante clasicista y más o menos liberal José Joaquín de Mora resulta patético, como cuando intenta ridiculizar el papel de la imaginación:

Espiritualizar la poesía, y llevarla a aquel estado de incomprensibilidad, en que las palabras no son más que vanos sonidos, y las ideas se pierden de puro sutiles y alambicadas; es querer que un arte de imitación no imite por falta de modelos y ejemplares, que sólo les puede prestar la naturaleza tangible y comprensible, y es empeñar a los pobres poetas a andarse por esos mundos de Dios buscando espectros y monstruos aéreos que los burlen a cada paso, y condenarlos a no dar nunca ni por descuido con la verosimilitud y la imitación (Carnero 1978: 170).

La cita de Schlegel, siempre de oídas y más o menos filtrada por Böhl, da mucho juego a unos y a otros, como se comprueba. Un buen ejemplo de las dificultades que presentaba la aplicación de esas ideas al caso español

\footnotetext{
a escritores posteriores como Espronceda, es ésta: «Al igual que Alborg, a mí me parece que cualquier asociación exclusiva de romanticismo español con liberalismo e inquietud espiritual es insostenible."

16. La idea estaba ya en Campmany: «La falta de lectura de nuestro pueblo le ha preservado de este contagio» (en Herrero 1971: 225, n. 3, quien la toma de Álvarez Junco).
} 
lo tenemos en Agustín Durán. Antes de la irrupción romántica de los años treinta, y desde posiciones conservadoras, este autor no deja de revelar la conciencia de la centralidad del sujeto romántico:

El objeto que el poeta se propone describir en ellas [sus creaciones] no es ciertamente al hombre abstracto y exterior; es, sí, al individual e interior: en los repliegues y en el más oculto secreto de la conciencia es donde busca el mérito y motivo de las acciones. [...] El objeto y fin que se proponen los poetas románticos [...] es, sí, el de retratar al hombre individual, dominado con más o menos vehemencia de las pasiones, vicios o virtudes de que es capaz el corazón humano; es, en fin, el de formar la historia del hombre interior, considerado como individuo, cuya conciencia íntima ha de penetrarse para juzgar motivo y mérito de sus acciones (Durán 1828: 83 y $85-86)$.

No ha de olvidarse que Durán destina sus observaciones al género dramático, género objetivo, según la definición hegeliana. Sin embargo, y a pesar del reconocimiento del "hombre interior» ${ }^{17}$, saltan en seguida las reticencias y cautelas ante la expresión subjetiva, sintetizadas en la fórmula religiosa y caballeresca:

Repetiremos, finalmente, que la sublime e ideal belleza de este último género se alimenta y sostiene en los inmensos espacios de la eternidad, en la sumisión del entendimiento humano a la fe divina y en la noble y generosa galantería de los siglos medios; de suerte que el mayor o menor entusiasmo religioso o caballeresco que pretende inspirar o de que se halla inspirado el poeta, es el único límite que éste impone a sus audaces metáforas y a sus grandes y sublimes pensamientos (Durán 1828: 86).

La «sumisión del entendimiento humano a la fe divina», después de lo visto en Blanco, no resulta esperanzador para el libre desarrollo de la subjetividad. Es más, en Durán -y estamos ya en 1828- las referencias al «hombre interior» están condicionadas por el mismo fenómeno de alteridad que alejaba a San Agustín de la experiencia contemporánea:

17. La misma expresión, «hombre interior», es recurrente en las cartas de Lista, en él contrapuesto al «hombre exterior» o «del foro» de Grecia y Roma (Juretschke 1951). 
El verdadero entusiasmo procede del éxtasis y arrobamiento del alma, que, desprendiéndose de las trabas del mundo real o prosaico, se eleva a las ideales regiones de la belleza poética, arrebatando, por decirlo así, del celestial modelo un rayo de luz divina, que no se presta a los cálculos exactos de la humana razón (Durán 1828: 63).

Sin embargo, como veíamos en Hegel y como demuestran los grandes líricos románticos europeos, es precisamente la objetivación de las «trabas del mundo real o prosaico" la que legitima el discurso literario de la subjetividad. La propuesta de Durán evita tanto los conflictos internos del hombre contemporáneo como sus circunstancias, el sudor y la sangre, el adoquín y el humo de los cigarros, para conducirnos directamente «a las ideales regiones de la belleza poética», donde ni se siente ni se padece. En ningún caso son prometedores para la constitución de una lírica ajustada al modelo hegeliano esa suma de neoplatonismo de manual con el rechazo de la razón ilustrada. No es éste, desde luego, el marco europeo en el que se desarrolla el principio romántico de la imaginación creadora.

A pesar de todo ello, en España será persistente el tópico de la ligazón del subjetivismo lírico con los modelos germánicos, tópico reactivado, años más tarde, en el entorno de la poesía becqueriana. La palabrería encubre en estos casos una profunda ignorancia de los modelos. Ya José Joaquín de Mora, en 1817, enredado en la polémica con Böhl -y apuntándolo sin duda-, hablaba de los alemanes como "seducidos por una sensibilidad excesiva» (Navas-Ruiz 1971: 27) ${ }^{18}$. Años más tarde, Alcalá Galiano escribirá, a propósito de la cuna alemana del romanticismo, que «lo que a nuestros ojos parecen rarezas de sus escritores, les es natural y está enlazado con sistemas filosóficos, llenos de misterio y oscuridad» (Alcalá Galiano 1834: 121). Aun así, buena parte de las supuestas novedades que se introducen a lo largo del XIX van a ir asociadas a lo alemán, amparadas primero en los elogios de los Schlegel al teatro áureo español, después en la intermediación de Böhl de Faber y más tarde -ya en etapa posromántica-al identificarlos como fuente de una inspiración más sobria e interiorizada, de lo que son ejemplo el auge de la

18. Francisco M. Tubino añadirá en su importante artículo de 1877 otros matices de interés para esta caracterización de lo alemán: «Alemán y romántico, que en aquellos días valía tanto como anti-francés, anti-revolucionario y cristiano ortodoxo» (Tubino 1877: 80). Böhl había escrito en los textos de su polémica con Mora: «Los apasionados de la poesía en Alemania, en particular los amantes de la sublime poesía española, son muy religiosos, muy morales y muy adictos a toda clase de orden» (Carnero 1978: 259). 
balada y del cantar o autores como Eulogio Florentino Sanz, Augusto Ferrán o el mismo Bécquer.

Habría que añadir en seguida que esto no está reñido con la evidencia de que los modelos efectivos de los románticos plenos están en Francia, y ello, aunque la galofobia actúe como argamasa del naciente nacionalismo español, progresista o conservador, alimentado en un caso con el rechazo del hipotético afrancesamiento de los ilustrados y en el otro con el nuevo "patriotismo" nacido en la guerra contra Napoleón ${ }^{19}$. Lo alemán es, de hecho, y al menos hasta mediado el siglo, antes un ideal abstracto que un modelo práctico de escritura. Se podría objetar que Zorrilla, por poner un ejemplo, hace efectivo el modelo schlegeliano al incorporar los moldes dramáticos seiscentistas -el teatro antiguo español, reivindicado sobre tal base por Böhl o Durán- o el medievalismo cristiano, entre otros rasgos. No obstante, se trata de una filtración ideológica, sin base textual alemana concreta -es decir, no directamente literaria-, pasada en la práctica por Francia, en la onda expansiva de Hernani. Esa base teórica es útil, por tanto, solamente en cuanto sirve para la recuperación de la tradición autóctona y para una consecuente toma de posición política conservadora.

Y yendo a la raíz, cabría preguntarse si existe de hecho una literatura propiamente romántica en el largo periodo que va desde la polémica suscitada por Böhl hasta la muerte de Fernando VII. Los textos literarios que podemos denominar con propiedad románticos no sólo son escasísimos, sino que se concentran en la última fase del reinado. Por más que Böhl de Faber propague su versión ultraconservadora de los Schlegel y que ésta fructifique en Agustín Durán o en los artículos de El Europeo, los referentes inevitablemente citados, volvemos a estar en el terreno de la teoría o de la crítica literarias, pero aún no en el de la creación, que es en última instancia lo que debiera interesar. ¿No sería lícito hablar de un cierto aroma dominante a ropavejero? Pero planteada la pregunta desde otro ángulo, ¿no será que esa interpretación del romanticismo, que anula la introspección libre y circunstanciada, impedía en la práctica la configuración de un cuerpo literario plenamente romántico?

19. La crítica al afrancesamiento de nuestra Ilustración es recurrente y va de la mano de paralelas descalificaciones ante lo que se considera desprecio e ignorancia de nuestra tradición literaria entre los ilustrados. Ecos de esa actitud se encuentran aún, sorprendentemente, en críticos actuales. No hará falta perder mucho tiempo en recordar que, por el contrario, la erudición dieciochesca es la que rescata del olvido no solamente grandes obras medievales, sino el enorme caudal de la lírica del XVI, por no hablar del papel institucional de la Real Academia. 
Ya hemos visto cómo en Agustín Durán, uno de los hitos en la apropiación del romanticismo schlegeliano, tampoco existe un asidero que nos permita hablar de conciencia de la subjetividad moderna, de imaginación creadora o de cualquiera otro rasgo realmente innovador. Solamente encuentro un pasaje que puede tener y tendrá de hecho paralelismo en la lírica, concretamente en la forma que tomarán muchos de los poemas más cercanos al objeto que perseguimos:

La metafísica de las pasiones y los monólogos largos son por esta causa indispensables al género romántico, pues sin ellos no podrían ni retratarse los sentimientos íntimos del alma y de la conciencia, ni graduarse la marcha imperceptible de los movimientos que a cada paso modifican al hombre individual (Durán 1828: 95, n. d.).

En realidad, Durán habla de teatro, aunque si nos tomásemos la libertad de ajustar el texto a un enfoque que contemple la poesía lírica, estaría describiendo lo que será el monólogo dramático, tan popular en el romanticismo europeo -incluido Espronceda, entre los españoles- y cuyas variantes inglesas estudió Langbaum (1996). Claro que él no lo sabía ni tenía por qué saberlo. No obstante, anotemos que Durán tampoco pone el acento en la inmersión en la subjetividad, con todo lo que ello arrastra. A fin de cuentas, aquí estamos de nuevo ante una táctica elusiva del yo confesional romántico. Lo que realmente le interesa va por otra dirección, la de los esquemas formales y formalistas, como son los que él denomina "monólogos largos», o a principios convenientemente abstractos y vagos, tópicamente schlegelianos, como "la metafísica de las pasiones».

En ambos casos, en Böhl y en Durán, estamos hablando de autores que sientan las bases sobre las que se asienta el desarrollo conservador del romanticismo español, o bien podríamos decir, a secas, del romanticismo español, pues Espronceda no hace verano. Tampoco Blanco White, por supuesto. El elogio de la modorra nacional que veíamos en cita anterior de Böhl es suficiente para situar el conflicto esencial. El desarrollo de la subjetividad libre, anclada en lo concreto, que alimenta la mejor poesía del romanticismo europeo, naufraga entre los españoles bajo los requerimientos del poder político y religioso. 


\section{Obras citadas}

Alcalá Galiano, Antonio, "Prólogo» a Ángel de Saavedra, El moro expósito, París, 1834. En Navas-Ruiz, ed., 1971, pp. 107-128.

Aullón de Haro, Pedro, "Construcción y disolución del sujeto estético-poético moderno", en La modernidad poética, la vanguardia y el creacionismo, Málaga Universidad de Málaga (Analecta Malacitana, Anejo XXVIII), 2000, pp. 23-28.

Blanco White, José, Cartas de España, 2a ed., Madrid: Alianza Editorial, 1977. - España, Sevilla: Alfar, 1982.

- Autobiografía de Blanco White, Sevilla: Universidad de Sevilla, 1988.

Cadalso, José, Cartas marruecas. Noches lúgubres, ed. E. Martínez Mata, Barcelona: Crítica, 2000.

Bloom, Harold, The anxiety of influence: a theory of poetry, Nueva York y Oxford: Oxford University Press, 1997.

Bürger, Christa, y Peter Bürger, La desaparición del sujeto. Una historia de la subjetividad de Montaigne a Blanchot, Madrid: Akal, 2001.

Carnero, Guillermo, Los orígenes del romanticismo reaccionario español. El matrimonio Böhl de Faber, Valencia: Universidad de Valencia, 1978.

Corbin, Alain, y Michelle Perrot, "Entre bastidores», en Philippe Ariès y Georges Duby, dirs., Historia de la vida privada, 4. De la Revolución francesa a la Primera Guerra mundial, Madrid: Taurus, 1989, pp. 419-620.

Díaz Corbelle, Nicomedes-Pastor, Poesía completa, ed. Luis Caparrós Esperante, Alicante: Universidad, 2006.

Dominique, Combe, «La referencia desdoblada: el sujeto lírico entre la ficción y la autobiografía», en Fernando Cabo Aseguinolaza, compil., Teorías sobre la lírica, Madrid: Arco/Libros, 1999, pp. 127-153.

Durán, Agustín, Discurso sobre el influjo que ha tenido la crítica moderna en la decadencia del teatro antiguo español y sobre el modo con que debe ser considerado para juzgar convenientemente de su mérito peculiar, Madrid: Imprenta de Ortega y Compañía, 1828. En Navas-Ruiz, ed., 1971, pp. 54-100.

Flitter, Derek, Teoría y critica del Romanticismo español, Cambridge: Cambridge University Press, 1995.

Foucault, Michel, Un diálogo sobre el poder y otras conversaciones, selección e introducción de Miguel Morey, Madrid: Alianza Editorial, 2001.

Gies, David T., ed., El Romanticismo, Madrid: Taurus, 1989.

Hegel, Georg W. F., Estética, Buenos Aires: Siglo Veinte, 1985. 8 vols.

Herrero, Javier, Los orígenes del pensamiento reaccionario español, Madrid: Edicusa, 1971.

Juretschke, Hans, Vida, obra y pensamiento de Alberto Lista, Madrid: CSIC, 1951.

Kirkpatrick, Susan, Las románticas. escritoras y subjetividad en España, 1835-1850,

Madrid: Cátedra, Universidad de Valencia e Instituto de la Mujer, 1991.

- «Blanco White en el confesonario», Quimera, 206 (2001), pp. 30-36.

Lagbaum, Robert, La poesía de la experiencia, Granada: Comares, 1996. 
Lista y Aragón, Alberto, Ensayos literarios y críticos, Sevilla: Calvo-Rubio y Compañía, 1844.

Menéndez Pelayo, Marcelino, Historia de los heterodoxos españoles, Madrid: Biblioteca de Autores Cristianos, 1998. 2 vols.

Navas-Ruiz, Ricardo, ed., El romanticismo español. Documentos, Salamanca: Anaya, 1971.

Schlegel, August Wilhelm, Cours de littérature dramatique, traduit de l'allemand par Mme. Necker de Saussure, nouvelle édition, revue et annotée par Eugène van Bemmel, Ginebra: Slatkine Reprints, 1971. Reproducción anastática de la ed. de 1865, que reeditaba la de París y Ginebra, 1814, autorizada por el autor.

San Agustín, Confesiones, trad. Pedro Rodríguez de Santidrián, Madrid: Alianza Editorial, 1999.

Tubino, Francisco M., «El romanticismo en España», Revista Contemporánea, 7 (15 y 30 de enero, 1877), pp. 79-98 y 184-198. Recogido en David T. Gies, ed., 1989, pp. 66-97.

Valera, Juan, «La poesía lírica y épica en la España del siglo XIX», en Obras completas, II. Critica literaria. Estudios criticos. Historia y politica. Miscelánea, Madrid: Aguilar, 1942, pp. 1169-1370. 
